\title{
Why Pandemics Matter to the History of U.S. State Development
}

\author{
Stephen Colbrook (D)
}

When a new strain of influenza circled the globe in the fall and winter of 1918, it swept through the United States at terrifying speed, infecting at least 25 million Americans-roughly onequarter of the population-over the next two years. Based on any metric, the pandemic was the country's largest mass-mortality episode of the twentieth century, killing approximately 675,000 Americans and surpassing the death toll of World War I. ${ }^{1}$ Even as the virus struck the United States with unprecedented ferocity, however, the federal government left most public health decisions to the states, producing a disjointed and hyper-localized approach to a crisis that was national and global in scope. In the absence of a strong federal role, state governments carved out their own policy paths, adopting widely divergent strategies to stem the spread of the disease. This preventive playing field was wildly uneven. Some states were well-equipped with robust public health infrastructures; others lacked the tools to manage the disease's rampant spread. ${ }^{2}$

More than sixty years later, in the early 1980s, state governments were at the vanguard of the public health response to another rampant pandemic-HIV/AIDS. The disease triggered a wave of legislation from California to Utah: by 1988, the states had enacted over 200 HIV-specific bills. ${ }^{3}$ State and local bureaucracies bore the brunt of the work during the epidemic's early years, as federal health agencies reeled under a series of budget cuts enacted by the Reagan administration. Rebuffed at the national level, AIDS activists and policy elites turned to state legislatures to address a host of concerns stemming from the pandemic, including the high cost of drug therapies, the rampant discrimination experienced by those suspected of infection, and the housing and healthcare needs of people living with $\mathrm{HIV}^{4}$

These parallels between the "Spanish flu" and the AIDS epidemic stand at odds with accepted narratives about twentieth-century U.S. state development, which trace the emergence of a modern liberal state centered around new forms of administrative and bureaucratic authority and the protection of individual rights. ${ }^{5}$ At the beginning of both outbreaks, the federal government lacked the tools to coordinate the nation's approach to a raging infectious disease.

I am tremendously grateful to Jonathan Bell, Gareth Davies, Elizabeth Evens, Pamela Haag, Beatrix Hoffman, Cherish Watton, Nick Witham, and the anonymous peer reviewer for their insightful feedback on various drafts of this article. Brooke Blower provided invaluable support and editorial guidance throughout the write-up process that significantly strengthened the quality of the final piece. This essay was completed with the financial support of the Wolfson Foundation.

${ }^{1}$ Both these statistics are taken from Nancy K. Bristow, American Pandemic: The Lost Worlds of the 1918 Influenza Epidemic (New York, 2012), 3-4.

${ }^{2}$ For a sample of the different community responses to the 1918 influenza pandemic, see the collection of essays produced by the Influenza Encyclopedia: The American Influenza Epidemic of 1918-1919: A Digital Encyclopedia, https://www.influenzaarchive.org/cities/index.html (accessed Oct. 12, 2021).

${ }^{3}$ Intergovernmental Health Policy Project, “A Synopsis of State AIDS Laws Enacted during the 1983-1987 Legislative Sessions” (Washington, DC, 1988), folder 29, box 131, National Gay and Lesbian Taskforce Records, Division of Rare and Manuscript Collections, Cornell University Library, Ithaca, NY [hereafter NGLTR].

${ }^{4}$ On the initial state-level response to HIV/AIDS, see Stephen Colbrook, "Clandestine Networks and Closeted Bureaucrats: AIDS and the Forming of a Gay Policy Network in California," Journal of Policy History (forthcoming).

${ }^{5}$ On how current scholarship focuses on the total supremacy of the American state after World War II, see Karen M. Tani, "Constitutionalization as Statecraft: Vagrant Nation and the Modern American State," Law \& Social Inquiry 43, no. 4 (Fall 2018): 1646-57.

(c) The Author(s), 2021. Published by Cambridge University Press 
The most striking continuity between the two pandemics was the fragility and weakness of the central state's public health authority. By contrast, in almost every other policy sphere, the power of the federal government expanded exponentially over the course of the twentieth century. The New Deal, two world wars, and the Great Society dramatically extended the central state's administrative apparatus and influence over the economy. An increasingly powerful federal government asserted new authority over policy areas traditionally controlled by states and municipalities: criminal justice, welfare, and education-to name just a few. ${ }^{6}$ In recent years, scholars have focused considerable attention on pervasive forms of state intervention that cut across partisan divides and outlasted the New Deal order: exploring the policing of sexual minorities by the "straight state," the bipartisan roots of the carceral state, and the rise of the national security state during the Cold War and War on Terror. ${ }^{7}$ These works reveal that even the late twentieth century was a period of state expansion and reconfiguration, not withdrawal or retrenchment.

Yet even with the consolidation of national authority in Washington, DC over the last century, the right to regulate public health and hygiene continued to rest primarily with the states and their municipalities. Far outpacing the central government in terms of spending and legislative activity on infectious disease control, state and local authorities often diverged markedly in their approaches to managing the spread of contagion. As a result, federalism repeatedly and decisively shaped the course of twentieth-century pandemics.

By asking why the states played a leading role in responding to pandemics during the twentieth century, how federalism constrained the national government's efforts to stem the spread of infectious diseases, and what epidemics reveal about the history of modern state-building, this article casts new light on the sprawling and intensely fractured nature of American governance. In so doing, it makes the case for greater dialogue between medical history and the history of twentieth-century U.S. state development. The literature on modern American pandemics is vast and continues to unfold in new directions, as scholars of medicine pay closer attention to the cultural politics of public health and the complex links between capitalism, racism, and infectious diseases. ${ }^{8}$ Yet, coverage of epidemics among historians of U.S. statecraft

\footnotetext{
${ }^{6}$ Elizabeth Hinton, From the War on Poverty to the War on Crime: The Making of Mass Incarceration in America (Cambridge, MA, 2016); Karen M. Tani, States of Dependency: Welfare, Rights, and American Governance, 19351972 (New York, 2016); Gareth Davies, See Government Grow: Education Politics from Johnson to Reagan (Lawrence, KS, 2007).

${ }^{7}$ For the history of the straight state, including works that explore its ramifications in the late twentieth century, see Margot Canaday, The Straight State: Sexuality and Citizenship in Twentieth-Century America (Princeton, NJ, 2009); Clayton Howard, The Closet and the Cul-de-Sac: The Politics of Sexual Privacy in Northern California (Philadelphia, 2019); and Scott De Orio, "Punishing Queer Sexuality in the Age of LGBT Rights" (Ph.D. diss., The University of Michigan, 2017). For a point of entry into the vast literature on the carceral state, see Heather Ann Thompson, "Why Mass Incarceration Matters: Rethinking Crisis, Decline, and Transformation in Postwar American History," Journal of American History 97, no. 3 (Dec. 2010): 703-34. On the rise of the national security state during the Cold War and the War on Terror, see Julian E. Zelizer, Arsenal of Democracy: The Politics of National Security-From World War II to the War on Terrorism (New York, 2010). These histories have supplanted an older master narrative of modern U.S. political history that focused on the rise and fall of the New Deal order-a declension narrative that often obscured key continuities in the organization of state power during the twentieth century. For the foundational work on the concept of the New Deal order, see Steve Fraser and Gary Gerstle, eds., The Rise and Fall of New Deal Order, 1930-1980 (Princeton, NJ, 1989). A useful point of entry into recent critiques of the "rise and fall" narrative of the New Deal order is Brent Cebul, Lily Geismer, and Mason B. Williams, eds., Shaped by the State: Toward a New Political History of the Twentieth Century (Chicago, 2019).

${ }^{8}$ The literature on nineteenth- and early twentieth-century epidemics is particularly extensive. See, for example, Michael Willrich, Pox: An American History (New York, 2011); Rana A. Hogarth, Medicalizing Blackness: Making Racial Differences in the Atlantic World, 1780-1840 (Chapel Hill, NC, 2017); and Kathryn Olivarius, "Immunity, Capital, and Power in Antebellum New Orleans," American Historical Review 124, no. 2 (Apr. 2019): 425-55. On the growing cultural visibility of emerging diseases after the 1990s, see Vassiliki Betty Smocovitis, "Someday a Big Plague Will Come: Laurie Garrett's The Coming Plague: Newly Emerging Diseases in a World Out of Balance," Isis
} 
remains far from even. The historiography of the twentieth-century American state says comparatively little about even world-historic outbreaks like the 1918 influenza pandemic, probably because of an ingrained assumption that epidemics are peripheral, episodic events that do not influence state formation. ${ }^{9}$ While scholarship produced over the last three decades has substantially improved our understanding of diseases such as the $1918 \mathrm{flu}$, polio, and HIV/AIDS, this work has not affected how most historians write and think about U.S. state development.

Equally significant is the lack of historical attention to state and local responses to modern epidemics, the organizational growth of federal agencies such as the Centers for Disease Control (CDC), and the implementation of national policies to address pandemic preparedness. ${ }^{10}$ Although public health is a critical component of modern governance, historians of the twentieth-century American state have curiously ignored it.

This article aims to repair this neglect by setting forth why the history of infectious disease deserves to figure more prominently in accounts of the twentieth-century American state. Returning the state to the study of modern epidemics and bringing public health governance back into our discussion of state-building over the last century, it argues that pandemics offer a particularly revealing window into the contested boundaries of government authority in the American federal system. By the closing decades of the twentieth century, public health was one of the few policy areas where the legal constraints of federalism continued to prevent the national government from taking a leading role. ${ }^{11}$ To explain why, this article introduces and

111, no. 4 (Dec. 2020): 814-7. Additionally, a veritable cottage industry of op-eds, journal articles, and books has analyzed twentieth-century pandemics through the lens of the COVID-19 crisis. See the American Historical Association's bibliography of historical commentaries and publications on the pandemic: "A Bibliography of Historians' Responses to COVID-19,” American Historical Association, https://www.historians.org/news-andadvocacy/everything-has-a-history/a-bibliography-of-historians-responses-to-covid-19 (accessed Oct. 12, 2021).

${ }^{9}$ Ever since the interdisciplinary movement to bring the state "back in" to studies of society and politics during the 1980s, the state has been a central topic and category of analysis in the field of modern American history, evidenced by the rapid proliferation of adjectives that scholars use to describe it-administrative, associational, carceral, imperial, Rube Goldberg, straight, submerged, and warfare-to name just a few. See Elisabeth S. Clemens, "Lineages of the Rube Goldberg State: Building and Blurring Public Programs, 1900-1940," in Rethinking Political Institutions: The Art of the State, eds. Ian Shapiro, Stephen Skowronek, and Daniel Galvin (New York, 2006), 187-215; and Gautham Rao, "The New Historiography of the Early Federal Government: Institutions, Contexts, and the Imperial State," William and Mary Quarterly 77, no. 1 (Jan. 2020), 97-128. Little or no reference, for example, is made to the 1918 influenza pandemic in canonical works such as Brian Balogh, The Associational State: American Governance in the Twentieth Century (Philadelphia, 2015); Christopher Capozolla, Uncle Sam Wants You: World War I and the Making of the Modern American Citizen (New York, 2010); Elisabeth S. Clemens, The People's Lobby: Organizational Innovation and the Rise of Interest Group Politics in the United States, 1890-1925 (Chicago, 1997); Jefferson Cowie, The Great Exception: The New Deal and the Limits of American Politics (Princeton, NJ, 2017); Gary Gerstle, Liberty and Coercion: The Paradox of American Government (Princeton, NJ, 2015); Jacob S. Hacker, The Divided Welfare State: The Battle over Public and Private Social Benefits in the United States (New York, 2002); Ellis W. Hawley, The Great War and the Search for a Modern Order: A History of the American People and Their Institutions, 1917-1933 (New York, 1979); and Stephen Skowronek, Building a New American State: The Expansion of National Administrative Capacities, 1877-1920 (New York, 1982). A number of agenda-setting edited collections on the history of the American state also contain no chapters on twentieth-century epidemics. For instance, see James T. Sparrow, William J. Novak, and Stephen W. Sawyer, eds., Boundaries of the State in U.S. History (Chicago, 2015); Cebul, Geismer, and Williams, Shaped by the State; and Gary Gerstle, Nelson Lichtenstein, and Alice O'Connor, eds., Beyond the New Deal Order: U.S. Politics from the Great Depression to the Great Recession (Philadelphia, 2019).

${ }^{10}$ For important exceptions, see James Colgrove, Epidemic City: The Politics of Public Health in New York (New York, 2011); John Mckiernan-González, Fevered Measures: Public Health and Race at the Texas-Mexico Border, 1848-1942 (Durham, NC, 2012); and Samuel Kelton Roberts Jr., Infectious Fear: Politics, Disease, and the Health Effects of Segregation (Chapel Hill, NC, 2009). The only monograph on the CDC's history was published nearly three decades ago in 1992, and its narrative ends in the early 1980s. See Elizabeth W. Etheridge, Sentinel for Health: A History of the Centers for Disease Control (Berkeley, CA, 1992).

${ }^{11}$ For examples of other areas of governance where the states continued to play a leading role, see Sara Mayeux and Karen Tani, "Federalism Anew," American Journal of Legal History 56, no. 1 (Mar. 2016): 128-38. 
analyzes the concept of "public health federalism," defined here as the complex web of laws and administrative structures, often derived from the legal doctrine of police power, that assigns responsibility for public health interventions to state and local governments. Three features of this governing arrangement deserve special attention. First, the history of public health federalism is one of striking continuity: across the twentieth century, states and localities remained at the leading edge of pandemic preparedness, despite the federal government's assertion of a more significant role in other aspects of American life from the 1930s onward. Second, public health federalism has often fueled intergovernmental friction between the states and the federal government, hampering efforts to implement a national approach to infectious disease control. A third and overarching component of public health federalism is that it nurtures healthcare inequalities between the states and their people by producing an uneven and fragmented approach to pandemics that often translates into stark regional differences in morbidity and mortality rates.

Bringing pandemics and statecraft into the same analytical frame demonstrates the degree to which the centralization of state power in the twentieth century co-existed with older, seemingly antithetical styles of governance rooted in nineteenth-century traditions of social regulation, community welfare, and local self-government. It illuminates what the political scientists Karen Orren and Stephen Skowronek have termed "intercurrence": the coexistence of multiple, overlapping governing orders at any single moment in the history of American statecraft. ${ }^{12}$ In other words, vestiges of an older political order, one that was a far-cry from what scholars identify as the key features of the modern liberal state, had remarkable staying power within the sphere of public health, surviving even through the expansion of federal power during the New Deal and Great Society eras.

The enduring power of public health federalism matters deeply. Such a legally decentralized system fuels wildly uneven responses to public health crises. Across the long sweep of the twentieth century, state governments failed to implement equitable eradication campaigns, perpetuating and even exacerbating racial, sexual, regional, and other health disparities. ${ }^{13}$

\section{Pandemics and Police Power in the Nineteenth Century}

Authority over public health was not one of the powers enumerated to the federal government by the U.S. Constitution, falling instead under the legal purview of the states. Throughout the early national period, states and municipalities regularly invoked the legal doctrine of police power, which endowed the states with an almost limitless capacity to regulate civil society for the public good. Derived from Anglo-American common law and sanctioned by the constitution, police power was part of what legal historian William Novak has termed the "wellregulated society," "... where the polity assumed control over, and became implicated in, the basic conduct of social life."14 Equipped with discretionary and vaguely defined authority, state legislatures broadly deployed their police powers in the nineteenth century, passing thousands of laws to regulate drunkenness, gambling, corporations, migration, workplace conditions, food inspections, guns, animals, fisheries, usury, highways, lotteries, and trade. ${ }^{15}$

In the early years of the American republic, when outbreaks of cholera, bubonic plague, and yellow fever struck cities with regular and devastating force, this governing philosophy also

\footnotetext{
${ }^{12}$ Karen Orren and Stephen Skowronek, The Search for American Political Development (New York, 2004), 16-17.

${ }^{13}$ On federalism, racial health disparities, and COVID-19, see Nicole Huberfeld, Sarah H. Gordon, and David K. Jones, "Federalism Complicates the Response to the COVID-19 Health and Economic Crisis: What Can Be Done?" Journal of Health Politics, Policy and Law 45, no. 6 (Dec. 2020): 951-65.

${ }^{14}$ William J. Novak, The People's Welfare: Law and Regulation in Nineteenth-Century America (Chapel Hill, NC, 1996), 14, 191-234.

${ }^{15}$ Gerstle, Liberty and Coercion, ch. 1; Jessica Wang, "Dogs and the Making of the American State: Voluntary Association, State Power, and the Politics of Animal Control in New York City, 1850-1920," Journal of American History 98, no. 4 (Mar. 2012): 998-1024; Kate Masur, "State Sovereignty and Migration before Reconstruction," Journal of the Civil War Era 9, no. 4 (Dec. 2019): 588-611.
} 
endowed the states with expansive legal authority to prevent the spread of infectious disease. Public health measures adopted in the face of looming pandemics therefore became a decisive force in shaping the contours of early American governance and in defining the boundaries of the states' sovereignty. The common law maxim salus populi suprema lex (the health of the people is the highest law) conveyed the well-established belief that individual rights were subordinate to the states' interest in promoting the public's health and well-being. Police power jurisprudence legitimated state efforts to quarantine the sick, enforce mandatory vaccination laws, and condemn unsanitary property. The grave threat that infectious diseases posed to a rapidly urbanizing society justified coercive health measures that curtailed individual freedoms and liberties. ${ }^{16}$

Throughout the nineteenth and early twentieth centuries, in dozens of cases at every jurisdictional level, the courts affirmed the states' legal authority to preserve and protect the public's health. Emblematic was the U.S. Supreme Court's decision in Jacobson v. Massachusetts (1905), which upheld the constitutionality of a mandatory smallpox vaccination law in Cambridge, Massachusetts. ${ }^{17}$ Conveying the view that the states were preeminent in the realm of public health, Supreme Court Justice John Marshall Harlan argued that "the safety and the health of the people of Massachusetts are, in the first instance, for that Commonwealth to guard and protect. They are matters that do not ordinarily concern the National Government." 18 Unlike many cases of its era, Jacobson endured well into the twenty-first century, with state and federal courts frequently citing it during the initial months of the COVID-19 pandemic. ${ }^{19}$

The federal government played a distinct but limited role in the regulation and promotion of public health during the nineteenth and early twentieth centuries. As early as 1798 , Congress established the national government's first public health program when it created the Marine Hospital Service (MHS) to treat merchant sailors. Although Congress initially legislated a narrow role for the MHS, centered around the operation of hospitals for mariners entering the United States, the agency's range of activities evolved over the course of the nineteenth century to include basic scientific research and interstate quarantine efforts. ${ }^{20}$ By the 1880 s and 1890s, the MHS had acquired a slew of new responsibilities, including formal control over the medical inspection of immigrants at the nation's borders and the authority to curb the interstate spread of yellow fever, smallpox, cholera, and the bubonic plague. ${ }^{21}$

During this same period, however, several ill-fated attempts to improve the nation's public health infrastructure fell victim to intergovernmental tensions. In 1879, following a devastating yellow fever epidemic in the south, Congress took the unprecedented step of creating a National Board of Health

\footnotetext{
${ }^{16}$ For more on the intersections between police power and public health, see Barbara Gutmann Rosenkrantz, Public Health and the State: Changing Views in Massachusetts, 1842-1936 (Cambridge, MA, 1972); Lawrence O. Gostin and Lindsay F. Wiley, Public Health Law: Power, Duty, Restraint, 3rd ed. (Oakland, CA, 2016); and Novak, The People's Welfare, 191-234.

${ }^{17}$ James Colgrove and Ronald Bayer, "Manifold Restraints: Liberty, Public Health, and the Legacy of Jacobson v. Massachusetts," American Journal of Public Health 95, no. 4 (April, 2005): 571-6. It is important to stress that Jacobson did recognize some limits to the states' public health authority. While offering a full defense of the police power, Justice Harlan argued that courts should intervene if it was used in a way that was "arbitrary and oppressive in particular cases." Jacobson v. Massachusetts, 197 U.S. 11, here 19 (1905). On the Janus-faced nature of Jacobson, see John Fabian Witt, American Contagions: Epidemics and the Law from Smallpox to COVID-19 (New Haven, CT, 2020), 57-9.

${ }^{18}$ Qtd. in Gostin, Public Health Law, 121.

${ }^{19}$ Wendy E. Parmet, "Rediscovering Jacobson in the Era of COVID-19," Boston University Law Review Online no. 100 (2020): 118-33, here 118-19; Wendy E. Parmet, "The COVID Cases: A Preliminary Assessment of Judicial Review of Public Health Powers During a Partisan and Polarized Pandemic," San Diego Law Review no. 57 (2020): 999-1048.

${ }^{20}$ Gautham Rao, "The Early American State 'in Action': The Federal Marine Hospitals, 1789-1860," in Boundaries of the State in U.S. History, eds. James T. Sparrow, William J. Novak, and Stephen W. Sawyer (Chicago, 2015), 21-56.

${ }^{21}$ Daniel Sledge, Health Divided: Public Health and Individual Medicine in the Making of the Modern American State (Lawrence, KS, 2017), 16.
} 
and empowered it with the authority to provide state and local health departments with technical expertise, collect vital statistics, and impose interstate quarantines. But, as the president of the Louisiana State Board of Health noted, many local administrators harbored deep suspicions about this perceived incursion into their domain and decried "the insolent pretensions of the National Board of Health with its odious system of espionage and intermeddling." 22 Unable to stem the growing tide of criticism against the board, Congress discontinued its funding in $1883 .^{23}$

The curtailment of the central state's authority by intergovernmental friction would recur so frequently over the following decades as to constitute a core component of American public health. To take just one further example, in the early 1910s, a sweeping legislative proposal for a national department of health faced a chorus of objections from state officials, federal bureaucrats, and, most prominently, Surgeon General Walter Wyman, who feared it would undermine the institutional autonomy of the MHS. ${ }^{24}$ Eventually, after vigorous debate, Congress passed a far more anemic bill in 1912 that made only a few statutory changes to the MHS's research authority and renamed it the Public Health Service (PHS). ${ }^{25}$ Four decades would pass before the establishment of the first cabinet-level position for health in $1953 .{ }^{26}$ Even as Populists and Progressives developed an administrative state capable of addressing some of the ills of unfettered capitalism, the federal government's reach in the sphere of public health remained limited.

\section{Progressive-Era Federalism and the 1918-1919 Influenza Pandemic}

The limits of the federal government's public health authority became starkly evident during the 1918-1919 influenza pandemic. A complex interplay of viral, biological, and social factors made it one of the deadliest pandemics in world history, killing some 50 million people. With a fatality rate of just under 2.5 percent, the virus was particularly virulent and contagious during 1918 , inflicting on its victims high fevers, extreme nausea, and deadly attacks of pneumonia. ${ }^{27}$ The growth of densely populated cities in the early twentieth century also facilitated the virus's spread. From the outset, public health professionals associated the disease with crowded urban spaces such as movie theaters, parades, and religious gatherings. In many respects, the "Spanish flu" was the first modern global pandemic - the first to occur in the contexts of mass transportation, total warfare, and rapid urbanization. ${ }^{28}$

In recent years, scholars have developed a rich understanding of the racialized and gendered nature of the American response to the $1918 \mathrm{flu}$ as well as its other cultural and social facets and effects. ${ }^{29}$ But they have not analyzed it in relation to the history of U.S. state development.

\footnotetext{
${ }^{22}$ Joseph Jones, Medical and Surgical Memoirs: Containing Investigations on the Geographical Distribution, Causes, Nature, Relations and Treatment of Various Diseases 1855-1890 (New Orleans, 1890), 299.

${ }^{23}$ Margaret Warner, "Local Control Versus National Interest: The Debate over Southern Public Health, 18781884," Journal of Southern History 50, no. 3 (Aug. 1984): 407-28; Margaret Humphreys, Yellow Fever and the South (Baltimore, 1992), 60-76; Jerrold M. Michael, “The National Board of Health: 1879-1883," Public Health Reports 126, no. 1 (Jan./Feb. 2011): 123-9.

${ }^{24}$ Manfred Waserman, "The Quest for a National Health Department in the Progressive Era," Bulletin of the History of Medicine 49, no. 3 (Fall 1975): 353-80.

${ }^{25}$ Sledge, Health Divided, 41.

${ }^{26}$ Martin Halliwell, American Health Crisis: One Hundred Years of Panic, Planning, and Politics (Oakland, CA, 2021), 4 .

${ }^{27}$ Jeffery K. Taubenberger and David M. Morens, "1918 Influenza: The Mother of All Pandemics," Emerging Infectious Diseases 12, no. 1 (Jan. 2006): 15-22.

${ }^{28}$ On the role of globalization in shaping the 1918-1919 influenza pandemic, see Nancy Tomes, "Destroyer and Teacher': Managing the Masses during the 1918-1919 Influenza Pandemic," Public Health Reports 125, no. 3 supplement (Apr. 2010), 48-62; and Siddharth Chandra, Julia Christensen, and Shimon Likhtman, "Connectivity and Seasonality: The 1918 Influenza and COVID-19 Pandemics in Global Perspective,” Journal of Global History 15, no. 3 (Nov. 2020): 408-20.

${ }^{29}$ For example, see Nancy K. Bristow, “'You Can't Do Anything for Influenza': Doctors, Nurses and the Power of Gender during the Influenza Epidemic in the United States," in The Spanish Influenza Pandemic of 1918-19: New
} 
Even monographs that focus on the American state's evolution during the First World War often mention the disease only in passing, treating it as a peripheral episode in the context of the war. ${ }^{30}$ But the pandemic constitutes more than an aberrational event or a devastating appendix to the First World War: it foreshadowed the consequential role American federalism would play in shaping the nation's approach to modern epidemics.

Although the influenza catastrophe was unprecedented in its size and scope, the federal government nevertheless proved unable and unwilling to coordinate the nation's response. Only in October 1918, as the second wave of the pandemic reached its crest, did Surgeon General Rupert Blue begin issuing public statements on influenza management. ${ }^{31}$ Congress infused the PHS with $\$ 1$ million of extra funding to fight the outbreak, but this figure amounted to less than one-third of what New York City alone spent on public health in $1918 .^{32}$ From the beginning, the Health Service signaled its constitutionally subordinate role to state and local governments, aiming, as Surgeon General Blue put it, “... to aid and not supplant state and local health authorities in their work." Accordingly, "Instructions were issued that all request for medical, nursing, and other emergency aid in dealing with the epidemic should come to the Public Health Service only through the State Health Officers." ${ }^{33}$ Even as the pandemic sowed death and panic, Woodrow Wilson never made a public statement about it, opting to ignore the danger it posed rather than divert attention away from the war effort. ${ }^{34}$

In the absence of a clear federal role, state and local authorities dominated the public health response to influenza. Under the sweeping authority of the police power, states ordered schools, bars, and theaters to close; issued sweeping bans on non-essential public gatherings; placed restrictions on transportation; and imposed other unprecedented measures. Because of the sprawling and disjointed character of the nation's public health system, and because health experts could reach no consensus about which social-distancing measures were most effective, even basic epidemic control strategies spawned a myriad of different local variants. Decisions about which specific institutions to close-and for how long-generated particular controversy. Not surprisingly, those municipalities that imposed restrictions promptly-and kept them in place until the pandemic receded from view-lost fewer lives to the disease. ${ }^{35}$ With its advanced public health infrastructure, New York City acted quickly against the pandemic, mounting a largely effective response that led to the lowest mortality rate on the east coast. ${ }^{36}$ The city of Detroit, by contrast, was among the municipalities slow to impose public-gathering bans, because its Health Commissioner, James W. Inches, insisted that a prolonged closure of the

Perspectives, eds. Howard Phillips and David Killingray, (London, 2003), 58-70; Julia F. Irwin, “An Epidemic without Enmity: Explaining the Missing Ethnic Tensions in New Haven's 1918 Influenza Epidemic,” Urban History Review 36, no. 2 (Spring 2008): 5-17; and Christopher McKnight Nichols, Nancy Bristow, E. Thomas Ewing, Joseph M. Gabriel, Benjamin C. Montoya, and Elizabeth Outka, "Reconsidering the 1918-19 Influenza Pandemic in the Age of COVID-19," Journal of the Gilded Age and Progressive Era 19, no. 4 (Oct. 2020): 642-72.

${ }^{30}$ Capozzola, Uncle Sam Wants You, 51-52; Hawley, The Great War and the Search for a Modern Order, 29.

${ }^{31}$ Halliwell, American Health Crisis, 151.

${ }^{32}$ United States Bureau of the Census, Financial Statistics of Cities Having a Population of Over 30,000 (Washington, DC, 1918), 187; "Brief Outline of Activities of the Public Health Service in Combating the Influenza Epidemic: 1918-1919," file 1622, box 145, RG 90, National Archives and Records Administration, College Park, MD [hereafter NARA].

${ }^{33}$ Rupert Blue, "Epidemic Influenza and the U.S. Public Health Service," Modern Hospital 11 (Dec. 1918): 425-6.

${ }^{34}$ On the failure of presidential leadership during the $1918 \mathrm{flu}$, see John M. Barry, The Great Influenza: The Story of the Deadliest Plague in History (New York, 2005): 299-313.

${ }^{35}$ Recent work in the field of historical epidemiology has found that quick implementation of social-distancing measures reduced transmission of influenza by up to 50 percent in the fall of 1918. See Howard Markel, Harvey B. Lipman, J. Alexander Navarro, Alexandra Sloan, Joseph R. Michalsen, Alexandra Minna Stern, and Martin S. Cetron, "Nonpharmaceutical Interventions Implemented by US Cities During the 1918-1919 Influenza Pandemic," JAMA: The Journal of the American Medical Association 298, no. 6 (August 8, 2007): 644-654.

${ }^{36}$ Francesco Aimone, "The 1918 Influenza Epidemic in New York City: A Review of the Public Health Response," Public Health Reports 125, no. 3 supplement (Apr. 2010): 71-9. 
city's businesses would cause more harm than good. When health leaders in other Michigan cities implemented a multitude of strict social-distancing measures, Inches only redoubled his resolve to keep Detroit open, lifting the city's closure order on November 6, 1918, well before the peak of the pandemic. ${ }^{37}$ Not wanting to incite panic among the city's large population, he downplayed the disease's danger and overstated his department's ability to control it, informing the public that "if you are otherwise in good health, the chances are over 200 to one that you will get well and be alright again in a short time." ${ }^{38}$ Despite Inches's optimism, or perhaps precisely because of it, the pandemic struck Detroit particularly hard: of the ten largest cities in the U.S. in 1918, Detroit experienced the fourth-highest mortality rate from the disease (see Table 1).

Friction between the federal government and the states, and between state governments and municipal authorities, quickly emerged as a defining feature of the American response to influenza. For example, the Surgeon General issued guidelines to state and municipal health departments, advising them to close their schools. ${ }^{39}$ But in New York, the health commissioner decided against suspending lessons, because he believed that children would fare better in the city's public education system than at home. ${ }^{40}$ As the virus hit Chicago, the city's health department likewise elected to improve its school inspection and hygiene programs instead of shutting down. ${ }^{41}$ The American Red Cross-since 1900 tied to the executive branch by federal charter-also found itself subordinated to the authority of state and local health officials. "Cooperate in every way with the local Boards of Health," Elizabeth Ross, the director of the Nursing Bureau for the New England Division, informed her colleagues: "Take great pains not to force [your] opinions or services or criticize in any way their actions." 42 Meanwhile, from Illinois to Michigan to Pennsylvania, fault lines also developed between state and local public health experts. Many municipal officials questioned-and sometimes even circumvented-statewide closure orders, complaining that such blanket interventions were ill-suited to the specific problems of urban public health. In Detroit, for instance, Health Commissioner Inches openly defied the Michigan Board of Health when he lifted the city's public gathering ban. ${ }^{43}$

Examining the fractured response to the 1918 influenza outbreak illuminates how the history of pandemics can modify conventional understandings of U.S. state development during the early twentieth century. The prevailing narrative is that World War I triggered an unprecedented flow of power to the central government in an array of different policy spheres. Many scholars have traced the origins of the surveillance state, the national security state, and the military-industrial complex to the expansion of federal power during the war years. ${ }^{44}$ The demands of total warfare legitimated a vast extension of the national government's reach into the everyday lives of its citizens, foreshadowing the rise of the modern federal leviathan under the auspices of the New Deal. Through price controls, rationing, conscription,

\footnotetext{
37“State Closing Ban Lifted for Friday," Detroit News, Nov. 7, 1918, 10.

${ }^{38}$ James W. Inches, "Spanish Influenza," Detroit Free Press, Oct. 10, 1918, 8.

${ }^{39}$ Blue, "Epidemic Influenza and the U.S. Public Health Service," 425.

40"Copeland Satisfied by Influenza Tour," New York Times, Oct. 30, 1918, 10.

${ }^{41}$ Alexandra Minna Stern, Mary Beth Reilly, Martin S. Cetron, and Howard Markel, "Better Off in School': School Medical Inspection as a Public Health Strategy During the 1918-1919 Influenza Pandemic in the United States," Public Health Reports 125, no. 3 supplement (Apr. 2010): 63-70, here 68.

${ }^{42}$ Qtd. in Bristow, American Pandemic, 105.

43““Ban Off,' Says Inches; 'No Sir,' Avers Sleeper,” Detroit Free Press, Nov. 5, 1918, 1, 3. For other examples of intergovernmental tension between state and city health officials, see Tomes, "Destroyer and Teacher," 53-4.

${ }^{44}$ Paul A. C. Koistinen, Planning War, Pursuing Peace: The Political Economy of American Warfare, 1920-1939 (Lawrence, KS, 1998); William H. Thomas Jr., Unsafe for Democracy: World War I and the U.S. Justice Department's Covert Campaign to Suppress Dissent (Madison, WI, 2008); Capozzola, Uncle Sam Wants You. See also Stephen R. Ortiz's reflections in Christopher Capozolla, et al., "Interchange: World War I," Journal of American History 102, no. 2 (Sept. 2015): 463-99, here 496-7.
} 
Table 1. Characteristics of the response to the 1918-1919 influenza pandemic in the ten most populous cities in the U.S. in 1920

\begin{tabular}{|c|c|c|c|c|}
\hline City & $\begin{array}{l}\text { Length of } \\
\text { public health } \\
\text { response } \\
\text { (days) }\end{array}$ & $\begin{array}{l}\text { Public health } \\
\text { expenditure, } 1918 \\
\quad(\$ \text { million })^{a}\end{array}$ & $\begin{array}{l}\text { Mandatory } \\
\text { school } \\
\text { closure }\end{array}$ & $\begin{array}{l}\text { Weekly excess } \\
\text { pneumonia and } \\
\text { influenza deaths } \\
\text { (deaths } / 100,000 \\
\text { population) }\end{array}$ \\
\hline Baltimore, MD & 43 & 0.3 & Yes & 559.3 \\
\hline Boston, MA & 50 & 0.6 & Yes & 710.0 \\
\hline Chicago, IL & 68 & 1.8 & No & 373.2 \\
\hline Cleveland, $\mathrm{OH}$ & 99 & 0.6 & Yes & 474.0 \\
\hline Detroit, MI & 23 & 0.7 & Yes & 637.0 \\
\hline $\begin{array}{l}\text { Los Angeles, } \\
\text { CA }\end{array}$ & 154 & 0.2 & Yes & 579.8 \\
\hline $\begin{array}{l}\text { New York City } \\
\text { NY }\end{array}$ & 73 & 3.4 & No & 452.3 \\
\hline $\begin{array}{l}\text { Philadelphia, } \\
\text { PA }\end{array}$ & 51 & 0.8 & Yes & 748.4 \\
\hline Pittsburgh, PA & 53 & 0.4 & Yes & 806.8 \\
\hline St. Louis, MO & 143 & 0.3 & Yes & 358.0 \\
\hline
\end{tabular}

${ }^{a}$ Public health expenditure includes expenditure on local health boards, the collection of epidemiological statistics, the treatment of communicable diseases, and food regulation.

${ }^{b}$ Average for the weeks between September 8, 1918, and February 22, 1919. Sources: Howard Markel, Harvey B Lipman, J Alexander Navarro, Alexandra Sloan, Joseph R. Michalsen, Alexandra Minna Stem, and Martin S Cetron, "Nonpharmaceutical Interventions Implemented by US Cities during the 1918-1919 Influenza Pandemic," JAMA 298, no. 6 (2007): 644-54; United States Bureau of the Census, Financial Statistics of Cities Having a Population of Over 30,000 (Washington, DC, 1918); Selwyn D. Collins, W. H. Frost, Mary Gover, and Edgar Sydcnstricker "Mortality from Influenza and Pneumonia in 50 Large Cities of the United States, 1910-1929," Public Health Reports (1896-1970) 45, no. 39 (Sep. 26, 1930): 2277-2328; "State Grip Decree: Close Up Detroit," Detroit Free Press, Oct. 19, 1918, 1; "State Closing Ban Lifted for Friday," Detroit News, November 7, 1918, 2.

censorship, surveillance, and propaganda, the central state tightened its grip over the economy, political speech, and American society. In the process, the relationship between the state and its citizens grew closer and more complex. However, the influenza pandemic exposed the limits of the national government's influence at this critical juncture in the history of the American state. Not even the wartime spike in sentiments of self-sacrifice and social responsibility could legitimate a truly national response to pandemic disease. Even as the federal government mobilized for total warfare, protecting the people from new viruses and epidemics remained the prerogative of states and municipalities. Only in the 1930s, with the arrival of "big government" more generally during the New Deal, did the central state begin to play an influential role in responding to pandemics.

\section{Public Health, Polio, and the New Deal Order}

Despite the Progressive-era flurry of reform to governance generally, the American public health system limped into the 1920s as fragmented and disjointed as ever. The United States had no national health department, and the PHS was still a relatively small agency whose budget plateaued in the years immediately following the influenza pandemic. Throughout the 1920s, the Health Service's single biggest expenditure continued to be the operation of Marine Hospitals, which consumed nearly 50 percent of its budget. ${ }^{45}$ A truly national approach

\footnotetext{
${ }^{45}$ U.S. Congress, House, Committee on Ways and Means, Economic Security Act: Hearings, 74 Cong. 1st sess., Jan. 28, 1935, 312. In 1921, Congress did pass the Sheppard-Towner Act, one of the national government's first
} 
to pandemic preparedness did not emerge until the 1930s when a surge of New Deal-era legislation empowered the federal government to play a more central role in the nation's public health infrastructure. Yet curiously, historians have all but ignored public health in their studies of this pivotal moment in U.S. state development. ${ }^{46}$

As growing numbers of Americans put faith in robust government during the 1930s and 1940 s, and as communicable diseases continued to threaten the nation's economic and social well-being, a diverse chorus of voices rose in favor of the idea that the central state should assume responsibility for regulating and promoting public health. This viewpoint found adherents among state health administrators, PHS officers, even southern Democrats. ${ }^{47}$ As the president of the Mississippi Board of Health mused in 1937, "A developing social consciousness is leading people generally to the conviction that community health is the concern-the paramount concern-of the state. Within the last decade this idea, more or less indefinite for a time, has crystallized into a new conception of the duties, responsibilities, and functions of government." 48

Passage of the Social Security Act in 1935 represented the pinnacle of New Deal efforts to expand federal involvement in public health. But to the dismay of many reformers, the chief drafters of the legislation retreated from an initial proposal for national health insurance in hopes of placating the powerful American Medical Association (AMA), which opposed any perceived encroachment by the central government into physicians' professional autonomy. As part of the resulting compromise, Title VI of the Social Security Act instead authorized $\$ 8$ million for a new grants-in-aid program-administered through the PHS-to assist state and local health departments. ${ }^{49}$ For the first time, the national government would play a decisive role in developing and coordinating the nation's public health infrastructure, which opened the door for an unprecedented degree of cooperation between the PHS and state and local health authorities. During the various congressional hearings over the Social Security Act, few objected to these public health provisions. ${ }^{50}$ State health officers were receptive to this new level of federal investment in public health because the Great Depression had triggered a

sweeping public health laws, which provided states with grants to establish infant welfare and prenatal health programs. This legislation did provide a significant boon to non-national health institutions, but the federal government's authority in the sphere of public health remained feeble and disjointed. In a 1926 report, the National Health Council, a consortium of voluntary medical organizations established in 1920, found that over 40 federal agencies and 5,000 civil servants had some responsibility for public health, with no clear oversight from the PHS. James A. Tobey, The National Government and Public Health (Baltimore, 1926), 380-6. For background on the political and legislative history of the Sheppard-Towner Act, see Molly Ladd-Taylor, "Federal Help for Mothers: The Rise and Fall of the Sheppard-Towner Act in the 1920s," in Gendered Domains: Rethinking Public and Private in Women's History: Essays from the Seventh Berkshire Conference on the History of Women, eds. Dorothy O. Helly and Susan Reverby (Ithaca, NY, 1992), 217-27.

${ }^{46}$ The one health history detail political historians do take note of is President Truman's failure to implement a universal health insurance program. For points of entry into this vast literature, see Colin Gordon, "Why No National Health Insurance in the U.S.? The Limits of Social Provision in War and Peace, 1941-1948," Journal of Policy History 9, no. 3 (July 1997): 277-310; and Monte M. Poen, Harry S. Truman Versus the Medical Lobby: The Genesis of Medicare (Columbia, MO, 1979).

${ }^{47}$ On the support of southern Democrats for increased federal involvement in public health, see Daniel Sledge, "War, Tropical Disease, and the Emergence of National Public Health Capacity in the United States," Studies in American Political Development 26, no. 2 (Oct. 2012): 125-62.

${ }^{48}$ Felix J. Underwood, “New Trends in Public Health,” Mississippi Doctor 15, no. 4 (Sept. 1937), 37-40, here 37.

${ }^{49}$ Sledge, Health Divided, 96-123; Alan Derickson, Health Security for All: Dreams of Universal Health Care in America (Baltimore, 2005), 65-78.

${ }^{50}$ Writing in the 1960s, Edwin Witte-one of the chief architects of the Social Security Act-recalled that Title VI was "throughout the congressional consideration of this measure a source of strength for the bill ... [State health officials] gave very strong testimony regarding the need for additional public health work." Edwin E. Witte, The Development of the Social Security Act: A Memorandum on the History of the Committee on Economic Security and Drafting and Legislative History of the Social Security Act (Madison, WI, 1962), 171, 173. 
sharp decline in their political and institutional clout. Municipal health departments' per capita expenditure plummeted by 30 percent between 1931 and 1934, and most health departments teetered on the edge of fiscal collapse. ${ }^{51}$ In a letter to the drafters of the Social Security Act, E. L. Bishop, a Tennessee health officer, explained his support for Title VI: "We are spending huge sums for the relief of almost every agency and for the maintenance of almost all other functions of government, but we are permitting our health agencies, so painstakingly developed through the last two or three decades, to perish from a lack of support." ${ }^{\prime 2}$

Title VI of the Social Security Act undoubtedly took federal involvement in public health to unprecedented heights, but out of political and pragmatic necessity, it did so by simultaneously enhancing the governing power of state and local authorities. ${ }^{53}$ To be eligible for Title VI funds, states had to, among other things, increase their spending on health and sanitation programs. ${ }^{54}$ As almost every state did so, total state appropriations for public health increased nearly sevenfold between 1935 and 1950, rising from $\$ 13$ million to $\$ 85$ million. ${ }^{55}$ Given broad discretionary control over the administration of Title VI, the PHS formulated a slew of new regulations, including training standards and rules of practice for state and local health administrators to follow. The agency also created dozens of new training programs that educated over 3,000 local government employees to a postgraduate level in 1937 alone. To conform with the new guidelines set by the PHS, state health officials expended a great deal of energy on professionalizing their ranks, adopting uniform personnel guidelines in $1936 .^{56}$

Many state legislatures also used Title VI funds to professionalize and bureaucratize their health departments. New Mexico led the way in 1935 by passing a statute that created ten new district health departments, each staffed with an epidemiologist, a public health nurse, and a sanitation official. ${ }^{57}$ Prior to this legislation, New Mexico had been a public health laggard relative to other states, experiencing the country's second-highest death rate from tuberculosis during the 1920 s. $^{58}$ With a steady stream of federal dollars bestowed by the Social Security Act, New Mexico's public health budget climbed nearly 200 percent between 1935 and 1946. ${ }^{59}$ Elsewhere, in places as varied as Georgia, Kansas, Missouri, Texas, and Wisconsin, the Social Security Act facilitated new programs in maternal and child health, venereal disease control, and rural sanitation, as well as the rapid growth of a more professionalized and dedicated corps of state health officers. These multifaceted initiatives invariably dwarfed previous public health efforts in terms of resources, size, and scope, reversing the budget austerity of the early Great Depression and producing powerful new state health bureaucracies. ${ }^{60}$

\footnotetext{
${ }^{51}$ Committee on Ways and Means, Economic Security Act, 185.

${ }^{52}$ Qtd. in ibid, 185-6.

${ }^{53}$ On New Dealers' approach to intergovernmental partnerships between local, state, and federal officials, see Tani, States of Dependency; Brent Cebul and Mason B. Williams, "Really and Truly a Partnership': The New Deal's Associational State and the Making of Postwar American Politics," in Cebul, Geismer, and Williams, Shaped by the State, 96-122; and Mason B. Williams, City of Ambition: FDR, La Guardia, and the Making of Modern New York (New York, 2014).

${ }^{54}$ Public Health Service, Ten Years of Federal Grants-in-Aid for Public Health, 1936-1946 (Washington, DC, 1948), 7; Harriet S, Pfister, Kansas State Board of Health (Lawrence, KS, 1955), 65.

${ }^{55}$ Valerie A. Earle, "Post-1935 Developments in Southern State Public Health Programs," American Journal of Public Health 41, no. 11 (Nov. 1951): 1403-9, here 1404.

${ }^{56}$ C. E. Waller, "Progress Under the Operation of Title VI of the Social Security Act," American Journal of Public Health 28, no. 11 (Nov. 1938): 1298-1304, here 1299 and 1301.

${ }^{57}$ Myrtle Greenfield, A History of Public Health in New Mexico (Albuquerque, NM, 1962), 33-4.

${ }^{58}$ Department of Commerce, Bureau of the Census, Vital Statistics Rates in the United States, 1900-1940 (Washington, DC, 1943), 402-32.

${ }^{59}$ Public Health Service, Ten Years of Federal Grants-in-Aid for Public Health, 7.

${ }^{60} \mathrm{~A}$ full account of the Social Security Act's impact on state public health departments has yet to be written, but a few state-level histories analyze the topic briefly. See Pfister, Kansas State Board of Health, 65-75; Thomas Franklin Abercrombie, A History of Public Health in Georgia, 1733-1950 (Atlanta, 1950), 137; and John Duffy, The Sanitarians: A History of American Public Health (Urbana, IL, 1992), 259-60.
} 
Considering the transformative impact of Title VI, it is surprising that the Social Security Act's public health programs often warrant only passing mention at best in leading histories of the New Deal. ${ }^{61}$

In the decade and a half after the passage of the Social Security Act, Congress enacted a series of additional statutes that expanded the PHS's role in coordinating the nation's public health work. These included the La Follette-Bulwinkle Act of 1938, which provided federal grants to states for venereal disease control programs; the Public Health Service Act of 1944, which codified and strengthened the role of the PHS; and the Hill-Burton Act of 1946, which funded federal hospital construction in underserved regions. ${ }^{62}$ Together, these laws solidified the federal government's commitment to supporting state and local health authorities and facilitated two decades of rapid expansion for the PHS, which saw its annual budget increase nearly twentyfold between 1934 and $1950 .^{63}$

Federal public health agencies subsequently ballooned. Emerging in 1946 from a wartime government program focused on eradicating malaria in the south, the Communicable Disease Center (CDC) quickly enhanced the federal government's role in coordinating efforts to prevent the spread of contagion. In the two decades after its founding, the CDC's activities expanded beyond its initial focus on tropical diseases into areas as diverse as smallpox eradication, disease surveillance, and family planning. ${ }^{64}$ After a brief period of inadequate funding, the agency enjoyed significant political support and resources: its budget increased at a rate of about 16 percent per year between 1953 and $1969 .{ }^{65}$ The emergence and rapid growth of the CDC deepened the institutional and regulatory reach of the central government over state and local health departments. Already in 1950, two of the nation's largest federated public health organizations-the American Public Health Association and the Association of State and Territorial Health Officials-acknowledged that the CDC was the nation's premier government agency for determining which communicable diseases to prioritize. ${ }^{66}$ As the CDC expanded, it carved out a central space for itself in the nation's public health infrastructure, coordinating the responses of state and local officials to over fifty disease outbreaks in 1959 alone. $^{67}$

However, one must be careful not to overstate the degree of change ushered in by the New Deal and subsequent developments. Federal health officials continued to face serious constraints on their authority and capacity. Traditional containment and control strategiessuch as quarantine and isolation-remained largely under the legal purview of the states. ${ }^{68}$

\footnotetext{
${ }^{61}$ David Kennedy's Freedom from Fear devotes two sentences to Title VI; Ira Katznelson's Fear Itself does not refer to public health; and Colin Gordon's Dead on Arrival mentions Title VI only once. David M. Kennedy, Freedom from Fear: The American People in Depression and War, 1929-1945 (New York, 1999), 263-4; Ira Katznelson, Fear Itself: The New Deal and the Origins of Our Time (New York, 2013); Colin Gordon, Dead on Arrival: The Politics of Health Care in Twentieth-Century America (Princeton, NJ, 2013), 17.

${ }^{62}$ On the Hill-Burton Act, see Beatrix Hoffman, Health Care for Some: Rights and Rationing in the United States Since 1930 (Chicago, 2012), 63-89. On the La Follette-Bulwinkle Act, see Allan M. Brandt, No Magic Bullet: A Social History of Venereal Disease in the United States Since 1880 (New York, 1985), 122-60. Surprisingly few works have analyzed the history of the 1944 Public Health Services Act, but for a brief overview, see Lynne Page Snyder, "Passage and Significance of the 1944 Public Health Service Act," Public Health Reports, 109, no. 6 (Nov.-Dec. 1994): 721-4.

${ }^{63}$ The Budget of the United States Government for the Fiscal Year Ending June 30, 1935 (Washington, DC, 1934), A61; The Budget of the United States Government for the Fiscal Year Ending June 30, 1951 (Washington, DC, 1950), A47.

${ }^{64}$ Etheridge, Sentinel for Health, 1-48.

${ }^{65}$ Dale Van Atta, With Honor: Melvin Laird in War, Peace, and Politics (Madison, WI, 2008), 90.

${ }^{66}$ S. B. Thacker and D. J. Sencer, "Centers for Disease Control," in International Encyclopedia of Public Health, ed. Kristian Heggenhougen (Oxford, UK, 2008), 549-55, here 550.

${ }^{67}$ The Budget of the United States Government for the Fiscal Year Ending June 30, 1961 (Washington, DC, 1960), 586.

${ }^{68}$ Wendy E. Parmet, “AIDS and Quarantine: The Revival of an Archaic Doctrine,” Hofstra Law Review 14, no. 1 (Fall 1985): 53-90.
} 
Meanwhile, the nation's public health infrastructure still consisted of a patchwork quilt of institutions, agencies, regulations, and laws, distributed across over 1,600 separate governmental units. $^{69}$ The enduring impact of federalism on Americans' health once again became clearest when confronted with large-scale disease outbreaks.

In 1957, a new pandemic strain of influenza circled the globe, arriving on U.S. shores in the spring. Although it lacked the lethality of the "Spanish flu," seldom causing pneumonia or acute respiratory distress, it still claimed an estimated two million lives worldwide. Despite important lessons learned since 1918, the $1957 \mathrm{flu}$ again prompted chaotic and uncoordinated responses from the U.S. government. The CDC did take on an authoritative role when the pandemic reached its crescendo in the fall of that year by expanding its surveillance infrastructure and coordinating the containment efforts of state and local health experts. ${ }^{70}$ But because this particular strain was relatively mild, agency officials did not encourage the kind of strict socialdistancing measures that state and local governments had used against the $1918 \mathrm{flu}$, pinning most of their hopes instead on the rapid distribution of a vaccine. Eisenhower, however, rebuffed repeated calls for a national vaccination program, insisting that the pharmaceutical industry would do enough to immunize Americans against the disease. In a memo written on October 3, 1957, a White House official noted that "vaccine manufacturers have agreed to voluntary distribution among States according to population ... This voluntary type of distribution system cannot be expected to be uniformly effective, but more stringent controls are not recommended at this time." ${ }^{71}$ This near-exclusive reliance on the private sector and free enterprise hampered efforts to contain the disease. Without government coordination, the vaccine rollout was painstakingly slow, and pharmaceutical corporations manufactured most of the doses only after the pandemic had already receded. ${ }^{72}$ Influenza continued to sweep through America unchecked by medicine or policy until the winter of 1958 .

In the mid-twentieth century, polio was more of a public health priority than influenza, and its history illustrates the delicate balance of power between the states and the federal government, even during the New Deal and Cold War eras. A terrifying viral infection that frequently caused paralysis in children, polio had left an indelible imprint on American society and culture from the moment that the first cases hit Vermont in 1894. The fear and uncertainty surrounding the disease extended past World War II, when outbreaks erupted summer after summer across the United States, even as other infectious diseases receded from view due to antibiotics, immunization, and improved living standards. ${ }^{73}$ When Dr. Jonas Salk of the University of Pittsburgh developed the first working polio vaccine in the early 1950s, parents quickly lined up to have their children immunized. ${ }^{74}$ In 1955, just after this scientific breakthrough, Congress enacted the Poliomyelitis Vaccination Assistance Act, which created the first national immunization program. This statute allotted over $\$ 30$ million for the distribution of the Salk

\footnotetext{
${ }^{69}$ This figure includes 48 state health departments and 1,577 municipal public health institutions. E. R. Coffey, "Public Health Expands Its Facilities Under Title VI-Federal Social Security Act," American Journal of Public Health and the Nation's Health 31, no. 4 (Apr. 1941): 297-304, here 302.

${ }^{70}$ D. A. Henderson, Brooke Courtney, Thomas V. Inglesby, Eric Toner, and Jennifer B. Nuzzo, "Public Health and Medical Responses to the 1957-58 Influenza Pandemic," Biosecurity and Bioterrorism: Biodefense Strategy, Practice, and Science 7, no. 3 (Sept. 2009): 266-7.

71 "Special Staff Note," Oct. 3, 1957, Toner Notes October, DDE Diary Series, Dwight D. Eisenhower Papers as President, box 27, Dwight D. Eisenhower Presidential Library, Abilene, KS [hereafter DEPL].

${ }^{72}$ J. Donald Millar and June Osborne, "Precursors of the Scientific Decision-Making Process Leading to the 1976 National Immunization Campaign," in History, Science, and Politics: Influenza in America, 1918-1976, ed. June Osborne (New York, 1977), 22-3.

${ }^{73}$ There is now a rich literature on the cultural and social aspects of polio in the postwar years. For points of entry, see David M. Oshinsky, Polio: An American Story (New York, 2005); and Heather Green Wooten, The Polio Years in Texas: Battling a Terrifying Unknown (College Station, TX, 2009).

${ }^{74}$ On the development of the Salk vaccine, see Jane Smith, Patenting the Sun: Polio and the Salk Vaccine (New York, 1991).
} 
vaccine, but each state retained the authority to determine who would receive these shots. ${ }^{75}$ The AMA, the Eisenhower administration, and Republican members of Congress all balked at a more ambitious proposal for universal childhood vaccination, fearing, in the words, of Senator Barry Goldwater, that it was "a backdoor approach to socialized medicine." once again, the federal government relied on private entities to do its public health work. The Eisenhower administration sidelined proposals for a more centralized approach to the production and distribution of the Salk vaccine, and instead left these responsibilities to the states and pharmaceutical corporations. ${ }^{77}$

Eisenhower's successor took a different tack. In February 1962, President John F. Kennedy announced his intention to vaccinate all American children against polio, with the help of "a nationwide vaccination program to stamp out" the disease. ${ }^{78}$ A few months later, after some wrangling over details, Congress passed the Vaccination Assistance Act, which gave states grants to immunize their citizens against diphtheria, pertussis, tetanus, and polio. ${ }^{79}$ The goal of this legislation, Health, Education, and Welfare Secretary Abraham Ribicoff explained, was to "provide federal leadership in assuring that [vaccines] will be so utilized as to achieve the maximum benefits and protection to the public." 80 The 1962 act moved away from simply providing federal dollars for vaccines: it expanded the CDC's role in coordinating state and local immunization efforts; it precipitated the broadscale distribution of federal educational material on childhood vaccination; and it provided non-national health departments with technical personnel. ${ }^{81}$ In its early years, the legislation had an impressive track record, contributing to a sharp decline in polio rates across the country. ${ }^{82}$ By the tail end of the 1960 s, the CDC was coordinating over 100 separate state and local immunization projects that covered 90 percent of the U.S. population. ${ }^{83}$

From the earliest phases of the New Deal to the late 1960s, American public health entered a new era, with three defining characteristics: a flow of federal dollars to non-national health departments through an array of new laws and grant-in-aid programs, most notably Title VI of the Social Security Act; increased regulatory oversight of public health work by the CDC; and unprecedented levels of cooperation and collaboration between health officials across all levels of government. Yet even as the federal government assumed more decision-making power, the day-to-day work of responding to epidemics still often took place at the state and local levels. National and subnational state-building efforts were mutually constitutive: the growth of federal administrative capacity went hand in hand with the consolidation of state and local health departments. The federal government turned again and again to the private

\footnotetext{
${ }^{75}$ On the legislative wrangling over the Poliomyelitis Vaccination Assistance Act of 1955, see Elena Conis, Vaccine Nation: America's Changing Relationship with Immunization (Chicago, 2015), 21-3.

${ }^{76}$ U.S. Congress, Senate, Committee on Labor and Public Welfare, Poliomyelitis Vaccine: Hearings, 84 Cong. 1st sess., June 14, 1955, 46.

${ }^{77}$ Patrick M. Vivier, "National Policies for Childhood Immunization in the United States: An Historical Perspective” (Ph.D. diss., Johns Hopkins University, 1996), 40.

${ }^{78}$ John F. Kennedy, "Special Message to the Congress on National Health Needs, February 27, 1962," in Public Papers of the Presidents of the United States: John F. Kennedy (Washington, DC, 1963), 165-73, here 168.

${ }^{79}$ On the political impetus behind the Vaccination Assistance Act, see Conis, Vaccine Nation, 19-38.

${ }^{80}$ U.S. Congress, House, Committee on Interstate and Foreign Commerce, Intensive Immunization Programs: Hearings, 87 Cong. 2nd sess., May 15, 1962, 1.

${ }^{81}$ James Colgrove, State of Immunity: The Politics of Vaccination in Twentieth-Century America (Berkeley, CA, 2006), 144-7; Vivier, "National Policies for Childhood Immunization in the United States," 66-105.

${ }^{82}$ Vivier, "National Policies for Childhood Immunization in the United States," 95.

${ }^{83}$ F. Robert Freckleton, "Progress and Horizons in Immunization," in Proceedings from the Fifth Annual Immunization Conference (San Diego, CA, Mar. 12-14, 1968), 2-6. Both presidents Jimmy Carter and Bill Clinton built on Kennedy's vaccine law by strengthening federal involvement in the area of mass immunization. The Clinton administration's vaccination initiative, enacted in 1993, was especially capacious, transforming vaccines into a government entitlement for certain groups of children: Elena Conis, "Measles and the Modern History of Vaccination," Public Health Reports 134, no. 2 (Mar./Apr. 2019): 118-25.
} 
sector for assistance with its public health work, which often meant, as before, fragmented and disjointed approaches to diseases such as influenza and polio.

\section{The AIDS Epidemic and the Rise of New Federalism}

Against a backdrop of escalating crises at home and abroad, Ronald Reagan won the presidential election in 1980 on the premise that an overzealous and interventionist central state had caused many of the nation's woes. Over the next eight years, he pushed legislation through Congress that slashed federal taxes, rolled back the regulatory power of the central government, and dismantled key components of the New Deal state. ${ }^{84}$ However, discrepancies between rhetoric and action were a hallmark of the Reagan administration, and there was often a tension between the president's call for limited government and policies that expanded the size of the central state. As he cut taxes, Reagan beefed up spending on national defense and the military-industrial complex, saddling the federal government with huge deficits that tripled over the course of his tenure. ${ }^{85}$

Yet in the realm of public health policy, there was less of a disconnect between the rhetoric of limited government and reality. Reagan's first steps as president made it clear that he resisted the regulatory role of federal health agencies like the CDC. His administration also sought legislative and policy changes to strengthen the states' decision-making powers-a "New Federalism" to recalibrate the balance of power between the federal government and nonnational governments. ${ }^{86}$ After six months of heated rhetoric on both sides of the aisle, Congress passed the president's showpiece enacting this philosophy, the Omnibus Budget Reconciliation Act of $1981 .{ }^{87}$ This legislation not only cut grant-in-aid programs for state and local governments but also transformed a wide array of categorical grants (that is, grants that Congress had earmarked for specific programs) into smaller block grants over which states had more discretion. In addition, it slashed the overall appropriation for federal public health programs by 30 percent, overturned many New Deal and Great Society health regulations, and eviscerated federal support for municipal health departments. ${ }^{88}$ Under Reagan's watch, the CDC faced sustained cutbacks, and federal expenditure on public health declined as a percentage of GDP by nearly half. ${ }^{89}$ With federal health agencies under fire, the states began to outspend the national government three-to-one on public health in the 1980s and 1990s (see Figure 1).

The shoring up of federalism in the 1980s and 1990s was most evident in the U.S. government's response to the AIDS crisis. It is well-known that the AIDS crisis took place amid a broader political backlash against gay rights, a surge of electoral support for the New Right, and a concerted effort by the GOP to court the Evangelical vote-all of which influenced the Reagan administration's response to the epidemic, which was notoriously slow and lackluster. ${ }^{90}$ At the CDC, budget cuts in the early 1980 s compromised its capacity to respond to AIDS: the agency only spent $\$ 1$ million on research into the disease between June 1981 and June 1982, compared to $\$ 7$ million spent on the more modest threat of Legionnaires' disease during the

\footnotetext{
${ }^{84}$ Gerstle, Liberty and Coercion, 318-9.

${ }^{85}$ On the growth of the national security state during the Reagan years, see Zelizer, Arsenal of Democracy, ch. 13.

${ }^{86}$ On the ideology of New Federalism, see Timothy Conlan, From New Federalism to Devolution: Twenty-Five Years of Intergovernmental Reform (Washington, DC, 1998).

${ }^{87}$ John F. Cogan, The High Cost of Good Intentions: A History of U.S. Federal Entitlement Programs (Stanford, CA, 2017), 295-305.

${ }^{88}$ William Shonick, Government and Health Services: Government's Role in the Development of U.S. Health Services, 1930-1980 (New York, 1995), 110-1.

${ }^{89}$ Statistic derived from National Health Expenditure Data, Centers for Medicare \& Medicaid Services (CMS), http://www.cms.hhs.gov/NationalHealthExpendData (accessed Oct. 12, 2021).

${ }^{90}$ Jennifer Brier, Infectious Ideas: U.S. Political Responses to the AIDS Crisis (Chapel Hill, NC, 2009), 78-121.
} 


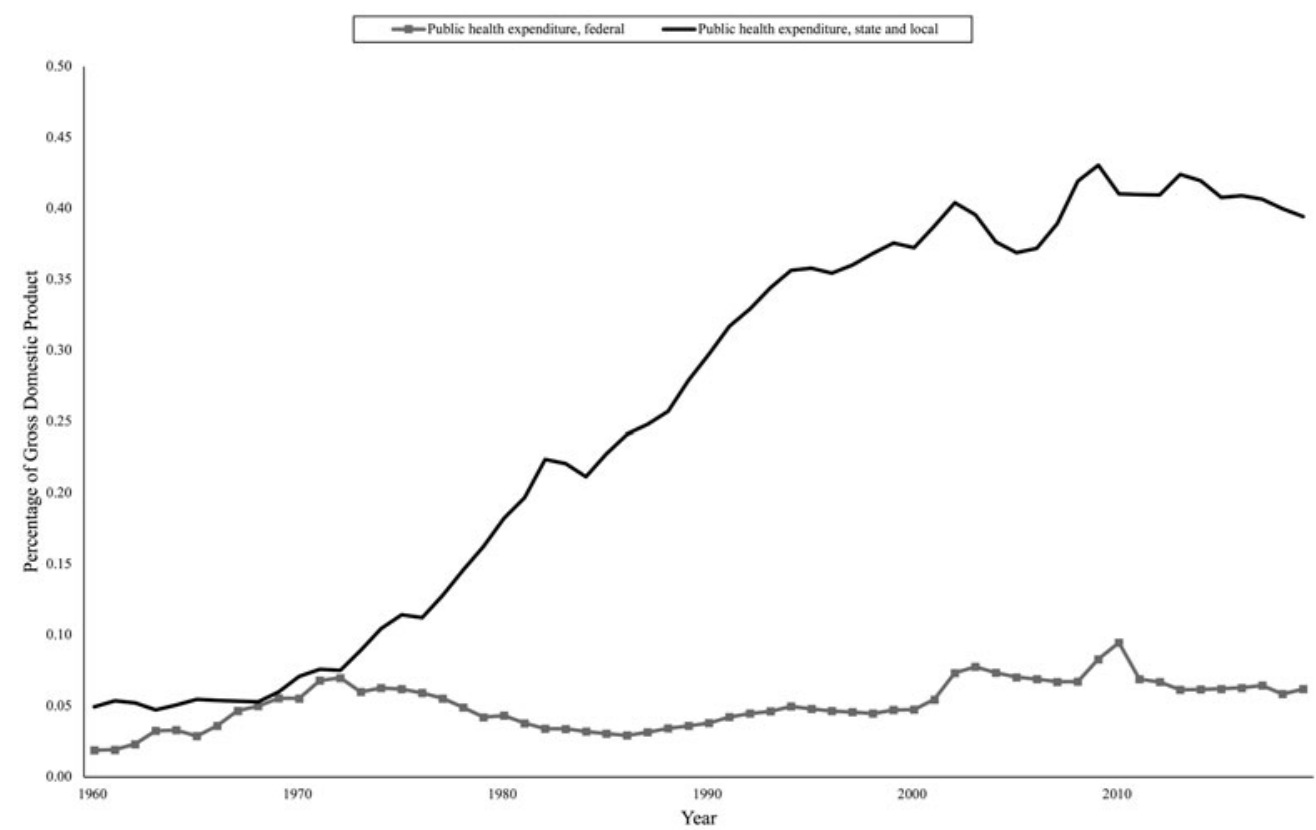

Figure 1. A comparison of federal public health expenditure with state and local public health expenditure, 1960-2019. Source. Centers for Medicare \& Medicaid Services (CMS), National Health Expenditure Data, www.cms.hhs.gov/ NationalHealthExpendData (accessed April 1, 2021).

late 1970s. ${ }^{91}$ Congress meanwhile did not enact its first AIDS-related law until 1988, seven years after the official start of the epidemic. ${ }^{92}$

Much of the rich and voluminous body of scholarship on the AIDS epidemic assumes, because of the Reagan administration's inaction and indifference, that all government failed to respond to the crisis. ${ }^{93}$ For the most part, state governments are absent from major works on the history of AIDS, and historians have yet to explain how federalism shaped the contours of early AIDS policy making. ${ }^{94}$ This absence is unfortunate because a striking feature of the U.S. approach to AIDS was the persistence of public health federalism and the fragmentation that it produced. While the federal response to the crisis was slow, the states enacted a flurry of AIDS-related statutes in the 1980s that ran the gamut from extremely coercive measures-including mandatory antibody testing and HIV criminalization-to antidiscrimination protections for people with AIDS (PWAs). On one issue after another, ranging from the politics of antibody testing to the funding of prevention education, states became policy incubators during the epidemic's early years. In 1987 alone, state legislators enacted

\footnotetext{
${ }^{91}$ Mary Ziegler, Beyond Abortion: Roe v. Wade and the Battle for Privacy (Cambridge, MA, 2018), 69.

${ }^{92}$ Irvin Molotsky, “Congress Passes Compromise AIDS Bill," New York Times, Oct. 14, 1988, A12.

${ }^{93}$ Historical scholarship on the AIDS epidemic has gathered steam over the last decade. For a sample of recent work, see René Esparza, “Qué Bonita Mi Tierra': Latinx AIDS Activism and Decolonial Queer Praxis in 1980s New York and Puerto Rico," Radical History Review, no. 140 (May 2021): 107-41; Jih-Fei Cheng, Alexandra Juhasz, and Nishant Shahani, eds., AIDS and the Distribution of Crises (Durham, NC, 2020); Karma R. Chávez, The Borders of AIDS: Race, Quarantine, and Resistance (Seattle, 2021); and Dan Royles, To Make the Wounded Whole: The African American Struggle Against HIV/AIDS (Chapel Hill, NC, 2020).

${ }^{94}$ Two exceptions are Colbrook, "Clandestine Networks and Closeted Bureaucrats"; and Stephen J. Inrig, North Carolina and the Problem of AIDS: Advocacy, Politics, and Race in the South (Chapel Hill, NC, 2011).
} 
over $140 \mathrm{HIV}$-specific bills and appropriated more funding for non-Medicaid-related AIDS healthcare than the federal government. ${ }^{95}$

As with earlier pandemics, this policy sprawl produced healthcare inequalities between the states. Some states made proactive efforts to stem the spread of the disease; others clustered around a draconian approach that undercut the civil liberties of people living with HIV infection. With its long tradition of rights activism and its vocal and well-organized gay movement, California led the way during the initial years of the epidemic, implementing an array of AIDS-related laws that expanded the state's prevention education programs, restricted the insurance industry's access to blood tests, and established the country's most robust anonymous testing regime. ${ }^{96}$ The California legislature anchored the efforts of a growing number of gay activists, policy makers, and legislative assistants who would later influence AIDS policy making at the national level. ${ }^{97}$ At one point, California accounted for half of all state-level expenditure on the epidemic. ${ }^{98}$ Other states, by contrast, focused the bulk of their energies on implementing extremely repressive AIDS measures that deepened the stigma attached to HIV/AIDS. With the concurrence of state and federal courts, state legislatures passed laws that criminalized "intentional" HIV transmission, imposed mandatory contact tracing on PWAs, and enforced closure orders against gay bathhouses. ${ }^{99}$ In the Illinois legislature, a powerful coalition of conservative lawmakers shepherded through a particularly repressive set of AIDS statutes. Facilitating this alliance was Penny Pullen, a long-time conservative activist and state representative from the Chicago suburb of Park Ridge. Much like conservatives at the national level, Pullen interpreted the AIDS epidemic as a symbol of moral decline and blamed gay men and IV drug users for the disease's spread. From Pullen's broad coalition emerged some of the most controversial AIDS legislation in the country, including a 1987 act that required antibody testing for all marriage license applicants. ${ }^{100}$

Yet other states chose to ignore the epidemic altogether. In the late 1980s, Texas had the nation's fourth largest HIV caseload but only spent fourteen cents per capita on the disease, compared to nearly three dollars in California and New York. ${ }^{101}$ In a state that still had a sodomy statute on the books, the mere idea of promoting safer gay sex to curb HIV was anathema to many legislators, medical professionals, and civil servants. ${ }^{102}$ Early in the epidemic, one lawmaker ignited a tinderbox of controversy when he compared funding AIDS programs to pouring money "down a rat hole." Only in 1989 did the Texas legislature pass its first major AIDS-related statute. ${ }^{103}$ In all these contexts, each state decided its own policies regarding HIV healthcare, civil liberty protections for PWAs, antibody testing, quarantines, and prevention education. All of this led to an eclectic, diffuse-and inequitable-response to AIDS.

The twenty-first century dawned with Americans' public health infrastructure as fragmented and decentralized as ever. Even with recurrent global outbreaks of newly emergent diseases such as the Ebola and Zika viruses, federal expenditure on public health rose only

\footnotetext{
${ }^{95}$ Intergovernmental Health Policy Project, "Summary of AIDS Laws from the 1987 Legislative Sessions," (Washington, DC, 1988), folder 31, box 131, NGLTR.

${ }^{96}$ Colbrook, "Clandestine Networks and Closeted Bureaucrats."

${ }^{97}$ Take, for example, the career trajectory of Steve Morin, who successfully lobbied the California legislature in the early 1980s for increased funding into biomedical research, eventually gaining enough prominence to become Nancy Pelosi's congressional assistant specializing in AIDS. Steve Morin, interview by the author, Oct. 19, 2018.

${ }^{98}$ Mona J. Rowe and Caitlin C. Ryan, "Comparing State-Only Expenditures for AIDS," American Journal of Public Health 78, no. 4 (Apr. 1988): 424-9.

${ }^{99}$ For a summary of this legislation, see Intergovernmental Health Policy Project, "A Synopsis of State AIDS Laws Enacted during the 1983-1987 Legislative Sessions” (Washington, DC, 1988), folder 29, box 131, NGLTR.

${ }^{100}$ John Kass, “AIDS Package Caters to Voters Back Home,” Chicago Tribune, July 1, 1987, 10.

${ }^{101}$ Bruce Lambert, "In Texas, AIDS Struggle Is Also Matter of Money," New York Times, Jan. 5, 1990, A18.

${ }^{102}$ Scott De Orio, "The Invention of Bad Gay Sex: Texas and the Creation of a Criminal Underclass of Gay People," Journal of the History of Sexuality 26, no. 1 (Jan. 2017): 53-87.

${ }^{103}$ Lambert, "In Texas, AIDS Struggle Is Also Matter of Money," 18.
} 
slightly during the Bill Clinton and George W. Bush administrations. ${ }^{104}$ President Barack Obama's signature legislative achievement, the 2010 Affordable Care Act, earmarked federal funds for several new public health initiatives, but appropriations for these programs have remained relatively meager over the last decade. ${ }^{105}$ Just as significant, the 2008 Great Recession imposed new fiscal restraints on state governments across the country, eroding their capacity to curb the spread of infectious diseases. In the decade following the financial crisis, state and local health departments lost an estimated 56,000 jobsapproximately one-fifth of their total workforce. ${ }^{106}$ "It was just chop, chop, chop," recalled one Michigan health official involved in budget talks during the early 2010 s. $^{107}$ Fiscal pressures were also evident at the national level: adjusted for inflation, the CDC's budget fell by 10 percent between 2010 and 2019. ${ }^{108}$ On the eve of the COVID-19 pandemic, then, the U.S. public health system was in disarray, beset by decades of chronic underinvestment, the fiscal pressures unleashed by the $2008 \mathrm{crash}$, and the absence of a clear role for the federal government.

\section{Conclusion}

States remained at the forefront of responding to public health crises throughout modern American history. Even such dramatic, disruptive, and historic events as pandemics have not spurred Americans to adopt more centralized, uniform approaches to healthcare.

But change may be coming in the form of a series of legal shifts, beginning with the rights revolution of the 1960s and 1970s, when the U.S. Supreme Court sharply curtailed the power of the states in areas of governance as diverse as education, voting rights, and criminal justice. In so doing, it enshrined constitutionally protected individual rights-such as equal protection, due process, and freedom of travel - that superseded the doctrine of police power. ${ }^{109}$ Public health law, as it developed during those same decades, aligned with this legal transformation: a raft of court decisions at every jurisdictional level found that medical patients were entitled to equal protection and due process guarantees, including the right to a fair hearing and to adequate notice. ${ }^{110}$ Typical was a decision handed down by the West Virginia Supreme Court in 1980, which struck down a tuberculosis quarantine statute because it did not provide adequate due process protections. ${ }^{111}$ Court decisions like this one imposed new constitutional constraints on public health authorities and raised new questions about the basic power of states to stem the spread of contagion. ${ }^{12}$

\footnotetext{
${ }^{104}$ David U. Himmelstein and Steffie Woolhandler, "Public Health's Falling Share of U.S. Health Spending," American Journal of Public Health 106, no. 1 (Jan. 2016): 56-7.

${ }^{105}$ In fiscal year 2015, appropriations for these programs stood at less than half of the $\$ 2$ billion initially budgeted for by the Affordable Care Act. Ibid, 57.

${ }^{106}$ Trust for America's Health, "The Impact of Chronic Underfunding of America's Public Health System: Trends, Risks, and Recommendations, 2020," Apr. 2020, 24, https:/www.tfah.org/wp-content/uploads/2020/04/ TFAH2020PublicHealthFunding.pdf (accessed Oct. 12, 2021).

${ }^{107}$ Qtd. in Sara Burnett, "In Years Before Outbreak, Investment in Public Health Fell," Associated Press News, April 5, 2020, https://apnews.com/article/health-ap-top-news-lansing-virus-outbreak-public-health-9960d22817a6402c 7693bee74ad2b75d (accessed Oct. 12, 2021).

${ }^{108}$ Trust for America's Health, "The Impact of Chronic Underfunding of America's Public Health System: Trends, Risks, and Recommendations, 2019,” Apr. 2019, 4, https://www.tfah.org/wp-content/uploads/2020/03/ TFAH_2019_PublicHealthFunding_07.pdf (accessed Oct. 12, 2021).

${ }^{109}$ Gary Gerstle, "The Resilient Power of the States across the Long Nineteenth Century: An Inquiry into a Pattern of American Governance," in The Unsustainable American State, eds. Lawrence Jacobs and Desmond King (New York, 2009), 61-87.

${ }^{110}$ Ronald Bayer and Laurence Dupuis, "Tuberculosis, Public Health, and Civil Liberties," Annual Review of Public Health 16 (May 1995): 307-26; Trevor Hoppe, Punishing Disease: HIV and the Criminalization of Sickness (Berkeley, CA, 2018), 27.

${ }^{111}$ Colgrove, Epidemic City, 207.

${ }^{112}$ Witt, American Contagions, 80.
} 
And as the historian John Fabian Witt notes, American law is now once again "in the midst of a little-noticed paradigm shift in courts' treatment of public health measures."113 During the first wave of COVID-19, when presented with a wave of constitutional challenges to socialdistancing measures in the spring of 2020, most federal and state courts refused to enjoin these emergency orders, accepting the states' compelling interest to protect the public from pandemic disease. ${ }^{114}$ But since late 2020 , Republican-appointed judges have partly dismantled the states' capacity to control COVID-19, striking down numerous laws designed to stop the disease's transmission. With the ascension of Justice Amy Coney Barret to the Supreme Court in October 2020, the ideological cast of the Court tilted yet further to the right, creating a new majority in favor of overturning emergency restrictions on religious gatherings. In a pivotal decision handed down in late November 2020, the Justices reversed New York state's limits on in-person church services, marking the first time that the Court invoked the right to free exercise of religion to strike down a COVID-related restriction. ${ }^{115} \mathrm{~A}$ bevy of other court decisions at the federal, state, and local levels have also begun to strip the states of their long-established autonomy in the realm of public health: the Wisconsin Supreme Court has enjoined the state's stay-at-home order, the U.S. District Court for the Western District of Pennsylvania has overturned the state's business closure ruling, and the Fifth Circuit Court of Appeals has lifted Holy Spring, Mississippi's ban on religious gatherings. ${ }^{116}$ These cases have collectively undermined the states' ability to control not only COVID-19, but also future pandemics. A new jurisprudence appears to be emerging that prioritizes individual libertiesespecially those related to religion-over the old maxim of salus populi suprema lex. As the courts continue to chip away at states' residual police power regarding public health, just who will have the authority to drive the response to the next pandemic remains an open question.

Stephen Colbrook is a Ph.D. candidate at University College London, where he is completing a thesis on the role of federalism in shaping the early political and policy response to the AIDS epidemic. His work has or will appear in the Journal of Policy History and Twentieth Century British History.

\footnotetext{
${ }^{113}$ John Fabian Witt, “Republican Judges Are Quietly Upending Public Health Laws,” New York Times, Oct. 15, 2020, https://www.nytimes.com/2020/10/15/opinion/coronavirus-health-courts.html (accessed Oct. 12, 2021).

${ }^{114}$ Parmet, "The COVID Cases."

${ }^{115}$ Roman Catholic Diocese of Brooklyn v. Cuomo, 592 U.S. (2020).

${ }^{116}$ Wisconsin Legislature v. Palm, 942 N.W.2d 900, here 912-8 (2020); County of Butler v. Wolf, Civil Action No. 2:20-cv-677 (2020); First Pentecostal Church v. City of Holly Springs, No. 20-60399 (2020).
} 